\title{
STUDY OF FOOD AND ENERGY VALUES OF NEW GINGERBREAD TYPES
}

\author{
Mikhail Kravchenko \\ Department of Technology and the organization of restaurant business \\ National University of Commerce and Economics \\ 19 Kyoto str., Kyiv, Ukraine, 02156 \\ ktogh@knteu.kiev.ua \\ Natalya Yaroshenko \\ Department of technology and restaurant organization \\ National Trade and Economics University \\ 19 Kyoto str., Kyiv, Ukraine, 02156 \\ ynatalya@email.ua
}

\begin{abstract}
The article deals with directions of the increase of the food value and decrease of the energetic value of gingerbread products. The results of the studies of the chemical composition of gingerbread products with food additives and changes in their composition were considered.

The perspective of the use of vegetable additives in gingerbread technologies was substantiated on the base of the analysis and generalization of theoretical, experimental data and production studies, and the possibility of their use was proved.

The use of food additives gives the possibility to raise the food and biological value, to widen the assortment of gingerbread products with prognosticated quality parameters, to form new consumption properties of a product to use the food potential of vegetable additives more full. It was proved, that new types of gingerbread products with vegetable additives have advantages over traditional ones.

New types of gingerbread products has the balanced chemical composition, low energetic value, decreased content of sugar and saturated fatty acids and increased content of healthy ingredients of the functional and prophylactic destination.

The addition of vegetable additives in the recipe of flour confectionary products leads to the increase of its food value at the expanse of protein quantity, change of food acids ratio in favor of unsaturated ones, enrichment with mineral substances and vitamins.

Keywords: cedar shot, sesame flour, phytopowder of snake bitterling, biological value, gingerbread products.
\end{abstract}

\section{Introduction}

Today the important role is given to the creation of new food products, enriched with biologically active substances, able to correct metabolic processes in the human organism, increase its protective functions, decrease the risk of different diseases development.

Flour confectionary products belong to the number of beloved products that are characterized with the permanently increasing demand of all population categories that is connected with low costs and high taste qualities [1]. The main shortcoming of gingerbreads is in the low food and biological value. Gingerbreads have nor enough biological substances, vitamins, mineral substances and food fibers. For giving gingerbreads functional properties and improving the chemical composition, the possibility of using biologically active substances as food additives was studied.

The production of functional food products that satisfy physiological needs of the human organism, realizing treating and prophylactic aims, is urgent for the food industry [2].

These products contain ingredients that raise the human immunity and are able to improve physiological processes in the organism: food fibers, vitamins, mineral substances, polyunsaturated fats, antioxidants, bifidobacteria, phospholipids, glycosides, amino acids and so on [3].

Flour confectionary products differ by the high content of sugar-sand that doesn't contain physiologically functional ingredients. In this connection the confectionary branch pays the great attention to the widening of the assortment of functional products. 
The one of ways of the solution of the problem of creation of flour confectionary products of the functional destination is the use of ecologically safe non-traditional additives of the vegetable origin, especially cedar shot, sesame flour and phytopowder from serpent bitterling.

For improving the biological value, the researches $[4,5]$ as to the raw material influence, possibility of its components use, interconnection between main nutrients and ready products quality were realized. Based on the combination of correspondent substances of shots and nontraditional raw material, new products of the deictic and treating-prophylactic destination are created. It is important to regulate the content of separate vitamins in different food products.

The use of new types of the raw material for the purposeful correction of the composition of flour confectionary products needs the elaboration of new technological decisions that provide the obtainment of high-quality and competitive ready products. In this connection the elaboration of effective production technologies of flour confectionary products with functional properties using shots and non-traditional raw material is urgent.

The aim of this research is the study of the possibility to increase the food value of flour confectionary products at the expanse of introduction of biologically active additives: cedar shot, sesame flour and phytopowder of snake bitterling.

The following tasks were set for attaining this aim:

- to master instrumental methods of the determination of physical-chemical quality parameters;

- to determine and to study the chemical composition of ready products;

- to carry out the comparative analysis of the influence of food additives on physical-chemical quality parameters and food value of ready products.

\section{Materials and methods}

Objects of researches - the energetic and food value of new types of gingerbreads with vegetable additives: cedar shot, sesame flour and phytopowder of a snake bitterling.

Subjects of researches - the control (produced of the traditional recipe of gingerbread dough), gingerbread products with vegetable additives: cedar shot, sesame flour and phytopowder of a snake bitterling.

Methods of researches - physical-chemical parameters are used in the work: determination of humidity, ashes mass share, quantity of protein and nitrogen, qualitative assessment of protein, coefficient of utilitarity of irreplaceable amino acids of protein, amino acid score, fatty-acid composition of gingerbreads, ascorbic acid, calculation of the food and energetic value.

Devices for the researches realization are presented on Fig. 1.

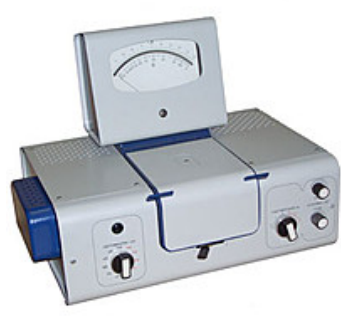

$a$

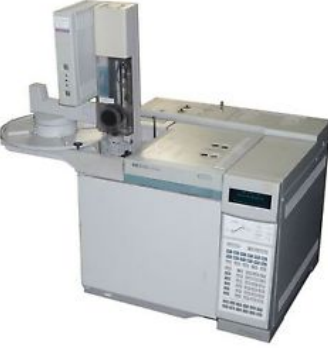

$b$

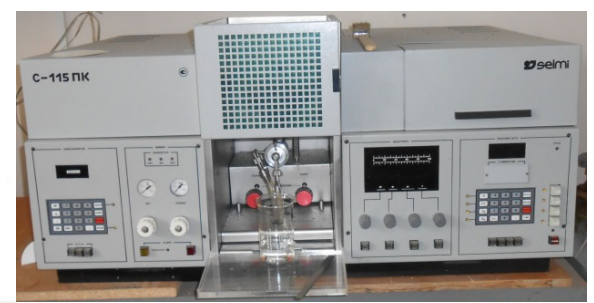

c

Fig. 1. Devices for the researches realization: $a$ - photocolorimeter CPC-2; $b$ - gas chromatograph N 6890; $c$ - spectrophotometer C-115 PC

The promising raw material for the enrichment of the food and energetic value is considered as cedar shot, sesame flour and phytopowder of snake bitterling.

Vegetable additives are characterized by the high content of easily-assimilated proteins that include all irreplaceable amino acids, polyunsaturated fatty acids, vitamins and mineral resources in a proper quantity. 
The use of cedar shot, sesame flour and phytopowder of snake bitterling at producing gingerbread products enriches these products with biological compounds, vitamins, mineral substances and food fibers.

For elaborating technology of gingerbreads production with vegetable additives, the control was chosen - the traditional recipe of gingerbread dough without adding cedar shot, sesame flour and phytopowder of snake bitterling [6]. Gingerbread products for the researches were chosen with adding the different quantity of vegetable additives.

Based on physical-chemical and technological properties of vegetable additives, there were established the limits of their content for the rational study. For the gingerbread "Cedar" the content of cedar shot was $14 \%$, gingerbread "Sesame" the content of sesame flour was $12 \%$, gingerbread "Roslynka" - the content of phytopowder of snake bitterling was $-8 \%$ of the mass of sesame flour of 1 sort.

The quantity of the raw material, included to the recipe of new gingerbread products is: wheat flour of 1 sort $-50 \%$, sugar $-20 \%$, cream butter $-5 \%$, eggs $2 \%$, honey $6 \%$, treacle $6 \%$, vegetable additives: cedar shot $-14 \%$, sesame flour $-12 \%$, phytopowder of snake bitterling $-8 \%$, baking powders $0,6 \%$, aromatizers $-0,4 \%$.

For obtaining reliable values of experimental data all researches were realized no less than trice, making two parallel determinations at each experiment.

Humidity was determined by drying to the constant mass at the temperature $105^{\circ} \mathrm{C}$ according to USST 4910:2008 [7].

Ashes mass share, insoluble in the solution with the mass share of saline acid $10 \%$ - by the wet ashing of a sample in nitrogenous acid and its burning in the electric stove according to USST 4672:2006 [8].

The determination of protein quantity in obtained fractions was realized by the Lowry method, modified by Miller using photocolorimeter CPC-2 in a dish with the working length $5 \times 10^{-3} \mathrm{~m}$ at the wave length $540 \mathrm{~nm}$. After colorimetring experimental solutions of fractions, the quantity of protein was determined by the calibrating graph, built using standard solutions of bovine serum albumin [9].

General nitrogen in vegetable additives and ready gingerbreads was determined by Kjeldahl method [10].

The qualitative assessment of protein relative to sample protein was realized by the method [11].

The coefficient of utilitarity of irreplaceable amino acids of $\varphi$ protein, as a numerical characteristic of their assimilability was calculated by the formula (1):

$$
\phi=\frac{8 \times \mathrm{Sc}_{\min }}{\sum_{\mathrm{i}=1}^{8} \mathrm{Sc}}
$$

where $\mathrm{Sc}_{\min }$ - value of the minimal score of amino acid.

Protein quality index $I_{p}$ was determined by the complex expression (2):

$$
I_{p}=\left\{\begin{array}{l}
1-\left(1-S_{\text {min }}\right) \times \phi, 0<\mathrm{Sc}_{\min }<1, \mathrm{Sc}_{\min }>1, \\
\mathrm{Q}_{\mathrm{up}}, \mathrm{Sc}=1,
\end{array}\right.
$$

The amino acid score, and also the degree of balance of irreplaceable amino acids of protein of wheat flour of 1 sort, vegetable additives and gingerbreads with their use were calculated by the method, offered by FAO/WHO [12].

The fatty-acid composition of gingerbread - is a method of gas chromatography on the gas chromatograph $6890 \mathrm{~N}$ [13].

The mineral composition of gingerbreads - was determined by the method of atomic-absorption spectrophotometry on the atomic-absorption spectrophotometers C-115 PC [14].

Ascorbic acid (vitamin C) was determined by Tillmans method [15]. 
The content of vitamins $\mathrm{B}_{2}$, PP, was determined by the methods, presented in works [16, 17]. Thiamine (vitamin $\mathrm{B}_{1}$ ) - was determined by the fluorimetric method that is in thiamine oxidation in the alkaline medium with thicrome creation [18].

The food value parameters are presented in the calculation for $100 \mathrm{~g}$ of edible part of a product, at that the content of proteins, fats and carbohydrates is presented in grams.

The calculation of the food and energetic value in gingerbreads was realized by the calculation method [19].

\section{Experiments}

Under modern conditions main directions of the food industry development are based on the increase of the biological value of products with minimal material and energetic costs. It is especially important at solving tasks of the population supply with food products that correspond to needs of all age groups and also for creating products of the special destination that realize the directed influence of the metabolic back ground of the organism [20].

The closest (control) to the offered method is the traditional one of stuff gingerbreads production [21], that includes the preparation of the invert and sugar syrupы for dough, preparation of the broth by mixing wheat flour of the first sort with preliminarily prepared syrups at the temperature $50-60{ }^{\circ} \mathrm{C}$, successive cooling of the broth and its mixing with bend, treacle, carbonic ammonium and bicarbonate sodium. But the shortcoming of this method is the insufficient number of microelements and vitamins and long technological process.

The base of the improved technology is the task of the increase of the food and biological value of stuff gingerbreads, giving them functional properties at the expanse of the protein share increase, balance of the fatty acid and mineral composition.

The set task is solved by the method of preparing stuff gingerbreads, at which the sesame flour share is replaced by a vegetable additive in the process of technological processing.

The replacement of flour is realized at the stage of dough mixing, at that cedar shot is preliminarily combined with sesame flour and assiduously mixed for its even distribution in the mixture. Such introduction method allows to carry out the technological process without changing the main stages of the gingerbread semi-product preparation.

The technological process of gingerbread products with vegetable additives that consists of the following operations: preparation of the raw material, preparation of a gingerbread semi-product, formation and baking of products, was improved at experiments.

Preparation of the raw material for the production

Flour, sugar, salt and bicarbonate sodium are sifted. Chicken eggs are processed according to the "Sanitary rules for confectionary workshops" [22]. Margarine is cleaned, cut in pieces.

Preparation of the gingerbread semi-product

The sugar-treacle syrup is prepared. Sugar, honey, treacle are dissolved in warm water. The syrup, cooled to the temperature $20^{\circ} \mathrm{C}$ is poured in the dough trough of the machine of dough mixing, eggs, baking powders, spices, melt margarine are added and assiduously mixed all ingredients during 5-8 $\mathrm{min}$. The mixed mass is added to the mixture of flour with cedar shot, and dough is mixed during 4-12 min.

Gingerbread dough has the even surface without clots and non-mixed traces, the color from the light-yellow to yellow, pleasant smell.

Formation

Ready dough is pressed to the thickness $7-8 \mathrm{~mm}$ and formed depending on the assortment of gingerbread products.

\section{Baking}

The baking duration $15-18 \mathrm{~min}$ at the temperature $190-210^{\circ} \mathrm{C}$.

The offered way of the production of gingerbread products with vegetable additives gives the new technical result: allows to get products with the increased content of vitamins, macro- and microelements and food fibers. The social effect from the introduction of elaborated products is the population supply with products of healthy food of the raised food value. 


\section{Results}

The food value of food products depends on the content of proteins, fats, hydrocarbons, mineral substances and vitamins in them. The biological value is determined by the quality of proteins, especially by the presence of irreplaceable amino acids, their ratio, speech of being attacked by digestive enzymes, presence of anti-nutrient substances. In the wider understanding the biological value provides the presence of other essential substances in a product - polyunsaturated fatty acids, mineral elements, vitamins and so on.

Based on the aforesaid, the technology of new gingerbreads production is described in the second section. The traditional recipe of gingerbread dough was taken as a control.

The general chemical composition of elaborated gingerbreads is presented in Table 1.

Table 1

General chemical composition of elaborated gingerbreads

\begin{tabular}{ccccc}
\hline Parameter name & Control gingerbread & "Cedar" gingerbread “Sesame" Gingerbread & "Roslynka" gingerbread \\
\hline Mass share of humidity, \% & 13,4 & 13,9 & 13,6 & 14,0 \\
Mass share of protein, \% & 8,3 & 10,2 & 10,1 & 8,6 \\
Mass share of fat, \% & 4,6 & 5,7 & 5,2 & 4,8 \\
Mass share of carbohydrates, \% & 72,6 & 68,4 & 69,6 & 70,6 \\
Mass share of ash, \% & 0,4 & 0,7 & 0,8 & 0,6
\end{tabular}

It was established, that elaborated gingerbread products "Cedar", "Sesame" and "Roslynka" with the different quantity of vegetable additives (cited in point 2.1) contain more protein by $21,9 \ldots 22,9 \%$, namely $11,7 \ldots 11,8 \%$, fat - more by $5,7 \ldots 24,5 \%$, namely $5,6 \ldots 6,6 \%$, ash - more by $20 \ldots 80 \%$, namely $0,6 \ldots 0,9 \%$, carbohydrates - less by $2,0 \ldots 5,3 \%$ in the recalculation for the dry substance comparing with the control sample, made by the traditional recipe. The calculation of the caloric value of elaborated gingerbreads testified that this parameter is $365,0 \mathrm{kcal}$ for control gingerbreads, for "Cedar" - 365,7 kcal, "Sesame" - 365,6 kcal, "Roslynka"- 357,6 kcal.

The analysis of the amino acid composition of gingerbreads (Fig. 2) demonstrated that the general quantity of irreplaceable amino acids in "Cedar" and "Sesame" gingerbread is more by $23,1 \ldots 28,9 \%$, in "Roslynka" gingerbread - more by $12,6 \%$ at the expanse of vegetable food additives use.

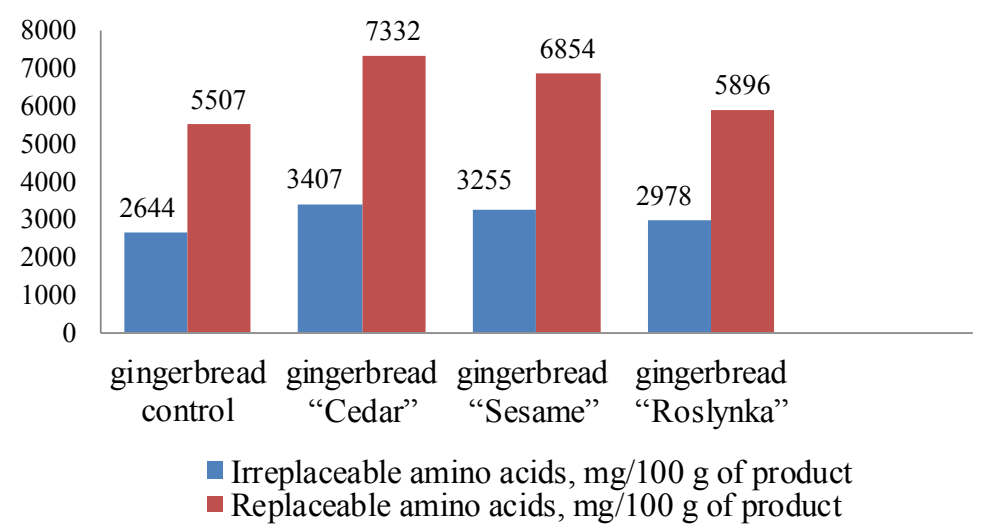

Fig. 2. Amino acid composition of elaborated gingerbreads

The analysis of the vitamin and mineral composition of elaborated amino acids proved the biological value increase (Table 2, 3). It was established, that the content of vitamin $\mathrm{E}$ in gingerbreads with vegetable additions increased in 1,5...11,7 times, vitamin $B_{1}$ - in 1,1..13,3 times, vita- 
$\min \mathrm{B}_{2}$ - in 3,0 ..31,0 times, vitamin PP - in 1,2 ..24,7 times. At that the gingerbread "Roslynka" contains vitamin $\mathrm{C}$ in amount of $2,05 \mathrm{mg}$.

Table 2

The vitamin composition of elaborated gingerbreads

\begin{tabular}{ccccc}
\hline Vitamin name & Control gingerbread & "Cedar" gingerbread & "Sesame" Gingerbread & "Roslynka" gingerbread \\
\hline E, mg & 1,06 & 12,40 & 8,20 & 1,60 \\
$\mathrm{~B}_{1}, \mathrm{mg}$ & 0,08 & 0,68 & 1,06 & 0,09 \\
$\mathrm{~B}_{2}, \mathrm{mg}$ & 0,02 & 0,62 & 0,21 & 0,06 \\
PP, $\mathrm{mg}$ & 0,60 & 14,80 & 9,50 & 0,70 \\
C, $\mathrm{mg}$ & - & - & - & 2,05
\end{tabular}

It was established (Table 3), that the sodium content in elaborated gingerbreads increased by $0,9 \ldots 5,0 \%$, potassium - by $14,8 \ldots 83,4 \%$, calcium - by $12,4 \ldots 26,9 \%$ - for gingerbreads "Cedar" and "Roslynka" and in 8,7 times in the gingerbread "Sesame", magnesium - by $9,6 \ldots 192,2 \%$, phosphorus - by $1,4 \ldots 116,7 \%$, iron - by $64,3 \%$ in the gingerbread "Cedar" and in 7,8 times in the gingerbread "Sesame", zinc - by 100,0..142,9\%, manganese - by $70 \%$ in the gingerbread "Cedar".

Table 3

Mineral composition of elaborated gingerbreads

\begin{tabular}{|c|c|c|c|c|}
\hline Element name & Control gingerbread & “Cedar" gingerbread & "Sesame" Gingerbread & "Roslynka" gingerbread \\
\hline $\mathrm{Na}, \mathrm{mg}$ & 105,7 & 110,9 & 111,0 & 107,6 \\
\hline $\mathrm{K}, \mathrm{mg}$ & 116,9 & 214,4 & 156,1 & 134,2 \\
\hline $\mathrm{Ca}, \mathrm{mg}$ & 20,1 & 22,6 & 174,7 & 25,5 \\
\hline $\mathrm{Mg}, \mathrm{mg}$ & 28,1 & 62,9 & 82,1 & 32,8 \\
\hline $\mathrm{P}, \mathrm{mg}$ & 83,7 & 181,4 & 151,2 & 86,9 \\
\hline $\mathrm{Fe}, \mathrm{mg}$ & 1,4 & 2,3 & 10,9 & 1,8 \\
\hline $\mathrm{Zn}, \mathrm{mg}$ & 0,7 & 1,7 & 1,4 & 0,9 \\
\hline $\mathrm{Mn}, \mathrm{mg}$ & 2,0 & 3,4 & 2,0 & 1,8 \\
\hline $\mathrm{I}, \mathrm{mg}$ & 5,9 & 7,2 & 7,0 & 6,7 \\
\hline $\mathrm{Se}, \mathrm{mg}$ & - & - & - & 0,18 \\
\hline
\end{tabular}

The offered method of the production of gingerbreads with vegetable additives has such advantages:

- the duration of products manufacturing decreases;

- at the lower energetic value gingerbreads have the higher biological value, increased content of vitamins, macro- and micro-elements and food fibers;

- structural-mechanical properties of gingerbreads improve;

- vegetable additives favor the deceleration of processes of products staling and fats oxidation.

It must be noted, that in experimental samples of gingerbreads the content of such mineral elements as potassium, phosphorus, sodium, magnesium, zinc, iodine are essentially higher than 
in gingerbread control samples. That is the elaborated sorts of gingerbreads differ by the presence of magnesium that activates the enzyme activity in the organism and decreases the risk of atherosclerosis. The studies demonstrated that gingerbreads, received by elaborated recipes include the essential quantity of vitamins in their composition. The introduction of vegetable additives in gingerbreads enriches them with vitamin $\mathrm{C}$, necessary for the normal human life activity, the essential increase of vitamins $\mathrm{E}, \mathrm{B}_{1}, \mathrm{~B}_{2}$, PP is observed.

\section{Conclusions}

1. The methods and methodologies for researches using new methods were determined.

2. The comparative analysis of the influence of vegetable additives on physical-chemical parameters of the quality and food value of ready products was realized.

3. It was established on the base of received results, that the use of vegetable additives in the composition of elaborated gingerbreads allows to increase the food and biological value at the expanse of the protein increase by $21,9 \ldots 22,9 \%$ (except the gingerbread "Roslynka") and improvement of the amino acid score, fat - by $5,7 . .24,5 \%$, first of all at the expanse of mineral substances, by $20 . .80 \%$ at the expanse of potassium, calcium, magnesium, phosphorus and iron. At that at the background of the protein and fat increase at the expanse of carbohydrates quantity decrease by $2,0 \ldots 5,3 \%$ the caloric value of the gingerbreads "Cedar" and "Sesame" remains stable, and "Roslynka's" one decreases by $2 \%$.

\section{References}

[1] Mazaraky, A. A., Peresichnyi, M. I., Kravchenko, M. F. (2012). Tekhnolohiia kharchovykh produktiv funktsionalnoho pryznachennia. Kyiv: Vydavnytstvo Natsionalnoho torhovelno-ekonomichnoho universytetu, 1116.

[2] Weststrate, J. A., van Poppel, G., Verschuren, P. M. (2002). Functional foods, trends and future. British Journal of Nutrition, 88 (2), 233-235. doi: 10.1079/bjn2002688

[3] Dubina, A. A., Letuta, T. M., Yancheva, M. O. et. al. (2015). Tovaroznavstvo produktiv funktsionalnoho pryznachennia. Kharkiv: Vydavnytstvo Derzhavnoho universytetu kharchuvannia i torhivli, 189.

[4] Ehorova, E. Yu., Batashova, N. V., Bochkarev, M. S. (2007). Biolohycheskaia tsennost i funktsyonalno-tekhnolohicheskie svoistva zhmykha yadra kedrovoho orekha. Maslozhyrovaia promyshlennost, $6,41-44$.

[5] Rohova, A. L., Ivanova, O. V., Panasova, T. H., Medved', L. M. (2008). Pidvyshchennia kharchovoi tsinnosti pisochnoho napivfabrykatu za rakhunok kedrovoho boroshna. Naukovyi visnyk Poltavskoho universytetu spozhyvchoi kooperatsii Ukrainy, 1 (28), 99-102.

[6] Rudavska, H. B., Tyshchenko, E. V., Prytulska, N. V. (2002). Naukovi pidkhody ta praktychni aspekty optymizatsii asortymentu produktiv spetsialnoho pryznachennia. Kyiv: Vydavnytstvo Natsionalnoho torhovelno-ekonomichnoho universytetu, 371.

[7] Drobot, V. I., Arsenieva, L. Y., Bilyk, O. A. (2006). Laboratornyi praktykum z tekhnolohii khlibopekarskoho ta makaronnoho vyrobnytstv. Kyiv: Vydavnytstvo Tsentr navchalnoi literatury, 314.

[8] Puchkova, L. Y. (2004). Laboratornyi praktykum po tekhnolohyi khlebopekarnoho proyzvodstva. Saint Petersburg: HYORD, 264.

[9] Lebedenko, T. Y., Pshenyshniuk, H. F. (2009). Metodychni vkazivky do vykonannia laboratornykh robit po kursu «Tekhnolohiia haluzi» rozdil «Tekhnolohiia khlibopekarskoho vyrobnytstva». Odessa: Vydavnytstvo Natsionalnoho universytetu kharchovykh tekhnolohii, 145.

[10] Fediukyn, V. K., Durnev, V. D., Lebedev, V. H. (2000). Metodi otsenki i upravleniia kachestvom promyshlennoi produktsyi. Moscow: Fylyn, 328.

[11] Melkyna, H. M., Anoshyna, O. M. (2006). Vvedenye v tekhnolohii produktov pytanyia. Laboratornyi praktykum. Moscow: Kolos, 254. 
[12] Pashchenko, L. P., Sanyna, T. V., Stoliarova, L. Y. et. al. (2007). Praktykum po tekhnolohyy khleba, kondyterskykh y makaronnykh izdelyi (tekhnolohyia khlebobulochnykh izdelyi). Moscow: Kolos, 215.

[13] Vynohradova, A. A., Mel'kina, G. M., Fomicheva, L. A. et. al.; Koval'skaia L. P. (Ed.) (1991). Laboratornyi praktykum po obshchei tekhnolohyi pyshchevykh proyzvodstv. Moscow: Ahropromyzdat, 335.

[14] Lebedenko, T. Y., Pshenyshniuk, H. F., Sokolova, N. Y. (2014). Tekhnolohiia khlibopekarskoho vyrobnytstva. Praktykum. Odessa: Osvita Ukrainy, 392.

[15] Skurykhyn, I. M. (2007). Tablytsy khymycheskoho sostava i kaloryinosti rossyiskykh produktov pytanyia. Moscow: DeLy, 276.

[16] Ylyna, O. A., Tsyhanova, T. B. (1995). Metodycheskie ukazanyia po raschetu pishchevoi tsennosty kondyterskykh yzdelyi dlia studentovspets. 2702 «Tekhnolohyia khleba, kondyterskykh, makaronnykh izdelyi i pyshchekontsentratov», 25.

[17] Skuratovskaia, O. D. (2001). Kontrol kachestva produktsyy fyzyko-khymycheskymy metodamy. Moscow: Vydavnytstvo DeLy prynt, 141.

[18] Syrokhman, I. V., Zavhorodnia, V. M. (2009). Tovaroznavstvo kharchovykh produktiv funktsionalnoho pryznachennia. Kyiv: Vydavnytstvo Tsentr uchbovoi literatury, 544.

[19] Antonov, A. P. (1986). Sbornyk retseptur muchnykh, kondyterskikh i bulochnykh izdelyi dlia predpryiatyi obshchestvennoho pitaniia. Moscow: Ekonomyka, 720.

[20] Ivanova, O. V., Kaplina, T. V. (2010). Sanitariia ta hihiiena zakladiv restorannoho hospodarstva. Sumy: Universytetska knyha, 399.

[21] Koriachkyna, S. Y., Osypova, H. A. (2012). Sovershenstvovanye tekhnolohyi khlebobulochnykh, kondyterskykh i makaronnykh yzdelyi funktsyonalnoho naznachenyia. Orel: FHBOU VPO «Hosunyversytet-UNPK», 262. 